\title{
DIGLOSIA
}

Volume 1, Nomor 2 (Agustus 2018)

ISSN 2615-725X (Print)

Halaman 101-114

eISSN 2615-8655 (Online)

\section{PENGEMBANGAN BAHAN AJAR MENULIS TEKS PROSEDUR KOMPLEKS DENGAN MODEL PEMBELAJARAN DISCOVERY LEARNING MENGGUNAKAN MEDIA AUDIO VISUAL (VIDEO) DI KELAS XI SMA NEGERI 1 SAMARINDA}

\author{
Paramita Candra Devi ${ }^{1, *}$, Yusak Hudiyono ${ }^{2}$, Widyatmike Gede Mulawarman ${ }^{3}$ \\ ${ }^{1}$ Magister Pendidikan Bahasa dan Sastra Indonesia, FKIP Universitas Mulawarman \\ ${ }^{2,3}$ Fakultas Keguruan dan Ilmu Pendidikan, Universitas Mulawarman \\ 1,*Pos-el korespondensi: paramitabitab8@gmail.com \\ ${ }^{2}$ Pos-el: yusak.hudiyono@fkip.unmul.ac.id \\ ${ }^{3}$ Pos-el: widyatmikegedemulawarman@yahoo.co.id
}

\begin{abstract}
This study aims to develop text learning materials to write complex procedures with learning discovery learning model using andio visual media (video). The research form used is research and development method (R\&D). The design used in the research and development of this teaching material adopted from Borg and Gall design model. This development research was conducted in SMA. The result of validation of this teaching material proved to be valid with the average of validation of content (material) $82 \%$ said valid, validation of $100 \%$ validity of the linguist, and the validation result of the media expert on the $93 \%$ video assessment stated very valid and on the handbook rating $84 \%$ students stated very valid. The results of the class XI test of SMA showed $86 \%$ stated very valid. From the result of data analysis through $t$-test formula yield $T_{\text {bitung }}(13,68)>$ $t_{\text {tabel }}(1,703)$, so there is cognitive difference between before and after student use instructional material developed in book with learning discovery learning modeling using audio-visual media with material text of complex class XI procedures. Then the results of the development that has been done to improve student learning outcomes.
\end{abstract}

Keywords: learning discovery learning model, teaching materials, audio visual media

\begin{abstract}
ABSTRAK
Penelitian ini bertujuan untuk mengembangkan bahan ajar menulis teks prosedur kompleks dengan model pembelajaran discovery learning menggunakan media audio visual (video). Bentuk penelitian yang digunakan adalah metode penelitian dan pengembangan (Reseacrh and Development). Desain yang digunakan dalam penelitian dan pengembangan bahan ajar ini mengadopsi dari model desain Borg and Gall. Penelitian pengembangan ini dilaksanakan di SMA. Hasil validasi bahan ajar ini terbukti valid dengan rata-rata dari validasi isi (materi) $82 \%$ meyatakan valid, hasil validasi ahli bahasa 100\% menyatakan sangat valid, dan hasil validasi ahli media pada penilaian video 93\% menyatakan sangat valid dan pada penilaian buku pegangan siswa $84 \%$ menyatakan sangat valid. Hasil ujicoba kelas XI SMA menunjukkan $86 \%$ menyatakan sangat valid. Dari hasil analisis data melalui rumus uji $t$-test menghasilkan $\mathrm{T}_{\text {hitung }}(13,68)>\mathrm{t}_{\text {tabel }}(1,703)$, sehingga terdapat perbedaan kognitif antara sebelum dan
\end{abstract}


sesudah siswa menggunakan bahan ajar yang dikembangkan dalam buku dengan pemodelan pembelajaran discovery learning menggunakan media audio visual dengan materi teks prosedur kompleks kelas XI. Maka hasil pengembangan yang telah dilakukan mampu meningkatkan hasil belajar siswa.

Kata kunci: model pembelajaran discovery learning, bahan ajar, media audio visual

\section{A. PENDAHULUAN}

Bahan ajar merupakan materi pembelajaran yang disampaikan guru kepada peserta didik, sehingga diperlukan bahan ajar yang mampu mewadahinya. Bahan ajar mempengaruhi keberhasilan peserta didik dalam proses belajar selain peranan seorang guru, maka dari itu perlu dirumuskan bahan ajar yang mampu mendukung terselenggarakannya pendidikan yang baik, khususnya dalam hal ini adalah mata pelajaran bahasa Indonesia. Idealnya materi pembelajaran harus relevan dengan kompetensi yang dibutuhkan, materi esensial, dan sesuai dengan tingkat perkembangan anak. Berkaitan dengan pembelajaran bahasa dan sastra Indonesia, sampai saat ini telah banyak bahan ajar yang dapat ditemukan, namun bahan ajar yang sesuai dengan kebutuhan guru dan peserta didik masih sulit ditemukan. Pada umumnya bahan ajar yang tersedia tersebut untuk kompetensi dasar secara keseluruhan baik untuk aspek keterampilan menyimak, berbicara, membaca, dan aspek keterampilan menulis.

Pembelajaran Bahasa Indonesia merupakan suatu kegiatan yang terencana dan mempunyai tujuan. Oleh karena itu, dalam pelaksanaannya antara lain diperlukan strategi dan model pembelajaran agar tujuan pembelajaran Bahasa Indonesia dapat tercapai. Guru sebagai komponen penting dari tenaga kependidikan, memiliki tugas untuk melaksanakan proses pembelajaran.

Dalam pelaksanaan pembelajaran guru diharapkan paham tentang pengertian strategi pembelajaran. Secara umum strategi dapat diartikan sebagai suatu garis-garis besar haluan untuk bertindak dalam usaha mencapai sasaran yang telah ditentukan. Bila dihubungkan dengan belajar mengajar, strategi juga bisa diartikan sebagai pola-pola umum kegiatan guru dan anak didik dalam kegiatan belajar mengajar untuk mencapai tujuan yang telah digariskan.

Proses belajar mengajar merupakan interaksi antara guru dan siswa serta lingkungan. Interaksi dalam pembelajaran sangat diperlukan untuk menjalin kerja sama antara guru dan siswa untuk saling mendapatkan umpan balik yang berguna untuk menambah ilmu. Hamalik (2013:57-64) menjelaskan pembelajaran sebagai suatu kombinasi yang tersusun meliputi unsur-unsur manusiawi, material, fasilitas, perlengkapan, dan prosedur yang saling mempengaruhi untuk mencapai tujuan pembelajaran.

Tujuan pembelajaran merupakan tercapainya suatu perilaku atau kompetensi pada siswa setelah mengikuti kegiatan pembelajaran. Upaya dalam merumuskan tujuan pembelajaran sangat bermanfaat bagi guru yang memudahkan mengkomunikasikan maksud kegiatan belajar mengajar, memudahkan guru dalam menyusun bahan ajar, serta memudahkan guru menyusun evaluasi dalam proses pembelajaran.

Proses pembelajaran harus diawali dengan perencanaan serta komunikasi yang baik. Kegiatan menyusun rencana pembelajaran merupakan salah satu tugas penting guru dalam memproses pembelajaran siswa agar dalam proses belajar mengajar terkonsep dengan baik dan teratur, maka seorang guru dituntut untuk mampu menyusun rencana 
pelaksanaan pembelajaran dan merumuskan tujuan secara jelas.

Sistematika penyusunan rencana pelaksanaan pembelajaran, pelaksanaan pembelajaran, serta evaluasi pembelajaran sejatinya harus mengacu pada kurikulum yang digunakan. Kurikulum yang digunakan sebagian sekolah pada saat ini yaitu kurikulum 2013. Dengan berubahnya kurikulum maka hal ini akan menjadi tantangan tersendiri bagi seorang guru. Sejauh mana guru telah mampu merealisasikan kurikulum 2013 dalam proses pembelajaran.

Kurikulum 2013 memuat standar kompetensi yang dirancang khusus untuk mengantisipasi perubahan kebutuhan, keterampilan, dan sikap agar peserta didik menghadapi tantangan pada perubahan zaman. Tujuannya antara lain agar peserta didik dapat memiliki kesempatan belajar beriman dan bertakwa kepada Tuhan yang Maha Esa, belajar memahami dan menghayati, belajar melaksanakan dan berbuat secara efektif, belajar hidup bersama dan berguna untuk orang lain, belajar membangun dan menemukan jati diri melalui proses belajar yang aktif, kreatif, dan menyenangkan. Melalui kurikulum 2013 ini, siswa diharapkan mampu memproduksi dan menggunakan teks sesuai dengan tujuan dan fungsi sosialnya. Dalam pembelajaran yang berbasis teks, bahasa Indonesia diajarkan bukan hanya sekedar sebagai pengetahuan bahasa semata, melainkan dengan teks yang mengemban fungsi untuk menjadi sumber aktualisasi diri penggunaannya pada konteks sosial budaya akademis. Teks dimaknai sebagai satuan bahasa yang mengungkapkan makna kontekstual.

Berkaitan dengan materi di dalam kurikulum 2013 untuk kelas XI ada beberapa jenis teks yang dimuat dalam pelajaran Bahasa Indonesia, terdiri atas dua jenis teks faktual yaitu laporan hasil observasi dan prosedur kompleks, dua jenis teks tanggapan yaitu teks negosiasi dan teks eksposisi, dan satu jenis teks cerita yaitu teks anekdot. Dalam penelitian ini akan difokuskan pada pembelajaran teks prosedur kompleks. Pentingnya pembelajaran teks prosedur kompleks ini karena teks ini memberikan informasi mengenai langkah-langkah atau suatu cara untuk mencapai tujuan yang diinginkan. Di dalam pembelajaran teks pada kurikulum 2013 terdapat hambatanhambatan yang diterima guru pada saat mengajarkan.

Salah satunya adalah teks prosedur kompleks yang berisi tentang langkahlangkah serta cara-cara yang ditempuh untuk menginginkan sesuatu agar tercapai. Hambatan tersebut antara lain guru tidak harus sepenuhnya memberikan materi, melainkan siswa sendiri yang harus menemukan pemahaman dari materi tersebut. Guru harus semaksimal mungkin menyusun rencana pelaksanaan pembelajaran agar dapat terlaksana dengan sesuai harapan.

Tidak sepenuhnya pembelajaran teks harus menggunakan pendekatan saintifik, tetapi dapat juga dipadupadankan dengan model-model pembelajaran agar siswa tidak jenuh saat berlangsungnya proses belajar mengajar. Serta dapat memudahkan guru dalam menerapkan model-model pembelajaran dengan pembelajaran teks pada khususnya tidak hanya pada teks prosedur kompleks.

Penggunaan metode atau model yang kurang tepat dapat menimbulkan kebosanan, kurang dipahami, dan monoton sehingga siswa kurang termotivasi untuk belajar. Pembelajaran teks prosedur kompleks yang biasanya hanya menggunakan pendekatan saintifik memang sudah membuat siswa aktif namun kurang dapat mengembangkan keterampilan sosial siswa yang kelak dapat berguna dalam kehidupan sosial.

Ada beberapa strategi serta model dalam pembelajaran Bahasa Indonesia berbasis teks, khususnya teks prosedur kompleks. Namun demikian, setiap model pembelajaran mempunyai tingkat 
keefektifan yang berbeda. Maka dari itu, perlu diterapkan dan dikembangkan model-model pembelajaran yang lebih efektif dan inovatif. Dengan demikian, siswa merasa lebih senang ketika mengikuti proses pembelajaran bahasa Indonesia berbasis teks pada umumnya dan pembelajaran teks prosedur kompleks pada khususnya.

Berdasarkan masalah yang terjadi terhadap kemampuan menulis teks prosedur, penulis menawarkan salah satu model pembelajaran penemuan (discovery learning). Diharapkan siswa dapat berkolaborasi dalam menyelesaikan masalah dengan model pembelajaran tersebut dan mampu menciptakan kondisi kelas yang aktif dan menyenangkan.

Menurut Hosnan (2014:280) menyatakan bahwa model pembelajaran penemuan (discovery learning) merupakan salah satu dari model yang dikembangkan pada kurikulum 2013. Model pembelajaran penemuan (discovery learning) merupakan suatu model pembelajaran yang mengaitkan permasalahan yang terjadi di dunia nyata. Masalah tersebut digunakan sebagai suatu konsep bagi siswa untuk menghasilkan cara berpikir kritis dan terampil dalam pemecahan masalah, serta untuk memperoleh pengetahuan. Pada prinsipnya siswa tidak diberi pengetahuan akan tetapi siswa harus menemukan sendiri hal yang baru.

Untuk mencapai tujuan kurikulum pembelajaran pada proses belajar mengajar maka perlu didukung media dan bahan ajar yang baik yaitu bahan ajar yang mampu menarik minat peserta didik, sesuai dengan zaman dan tidak menyimpang dari kurikulum. Penyajian materi pelajaran pada pokok bahasan dengan menggunakan video pendidikan diharapkan menarik minat peserta didik, membangkitkan gairah peserta didik untuk mempelajari kembali materi yang disajikan melalui multimedia (teks, citra, audio, video) materi yang disajikan dengan berbagai warna dan gambar yang sangat menarik dan sebagainya.

Melalui media yang telah dikembangkan peserta didik dapat menggunakan secara optimal alat indera yang dimilikinya. Semakin banyak alat indera yang digunakan oleh peserta didik maka sesuatu yang dipelajari akan makin mudah diterima dan diingat, akhirnya media dapat memotivasi peserta didik untuk belajar lebih baik. Selain penggunaan model pembelajaran, penggunaan media pembelajaran juga sangat diperlukan dalam kegiatan pembelajaran. Fakta di lapangan menunjukkan bahwa guru masih kurang dalam menggunakan media pada proses pembelajaran.

Dengan adanya media pembelajaran dapat membangkitkan semangat belajar siswa. Penggunaan media pembelajaran sangat membantu keefektifan proses pembelajaran, penyampaian pesan, dan isi pembelajaran pada saat itu. Selain membangkitkan motivasi dan minat siswa, media pembelajaran juga dapat membantu siswa meningkatkan pemahaman, menyajikan data dengan menarik dan terpercaya, memudahkan penafsiran data, dan memadatkan informasi. Salah satu media yang dapat digunakan oleh guru pada pembelajaran keterampilan menulis teks prosedur kompleks yaitu video.

Video merupakan media 5 yang masuk dalam kategori media audio visual. Dale (dalam Arsyad, 2013:27) mengemukakan bahwa bahan-bahan atau media audio visual dapat memberikan banyak manfaat asalkan guru berperan aktif dalam proses pembelajaran. Penggunaan media video digunakan karena video lebih efisien dan juga membuat hasil belajar lebih bermakna bagi kemampuan siswa, terutama dalam pembelajaran menulis teks prosedur kompleks. Siswa dimudahkan dalam menulis teks prosedur kompleks dengan adanya video. 
Video yang ditayangkan yaitu video aplikatif, yang bisa diterapkan siswa dalam kehidupan sehari-hari siswa di sekolah, terutama dalam lingkungan SMA. Video tersebut yaitu video tentang cara mudah dalam memahami materi pelajaran dan video cara mengatasi rasa kantuk pada saat pelajaran. Topik video tersebut dipilih berdasarkan masalah yang ada di lapangan khususnya kelas XI SMA. Berdasarkan latar belakang tersebut, peneliti berharap mampu mengembangkan model pembelajaran discovery learning pada materi struktur teks prosedur kompleks dengan menggunakan media pembelajaran audio visual.

\section{B. LANDASAN TEORI}

\section{Bahan Ajar}

Menurut Widodo dan Jasmadi dalam Ika Lestari (2013:1) bahan ajar adalah seperangkat sarana atau alat pembelajaran yang berisikan materi pembelajaran, metode, batasan-batasan dan cara mengevaluasi yang didesain secara sistematis dan menarik dalam rangka mencapai tujuan yang diharapkan, yaitu mencapai kompetensi dan subkompetensi dengan segala kompleksitasnya.

Bahan ajar adalah segala bentuk bahan yang digunakan oleh guru dalam melaksanakan kegiatan belajar mengajar di kelas. Bahan yang dimaksud bisa berupa bahan tertulis atau bahan tidak tertulis. Bahan ajar merupakan informasi, alat atau teks yang diperlukan oleh guru untuk perencanaan dan penelaahan implementasi pembelajaran. Bahan ajar juga bisa diartikan sebagai seperangkat materi yang disusun secara sistematis, baik tertulis maupun tidak tertulis sehingga tercipta lingkungan atau suasana yang memungkinkan siswa untuk belajar.

Mulyasa (2006:96) menyebutkan bentuk-bentuk bahan ajar sebagai berikut: bahan ajar dalam bentuk cetak, misalnya lembar kerja siswa (LKS), buku, modul, brosur, leaflet, wilchart, dan lain-lain, bahan ajar berbentuk audio visual, misalnya film/video dan VCD, bahan ajar berbentuk audio, misalnya kaset, radio, CD audio visual, misalnya foto, gambar, model/maket, multimedia, misalnya CD interaktif, computer based learning, internet.

\section{Menulis}

Menulis pada dasarnya adalah proses untuk mengemukakan ide dan gagasan dalam bahasa tulis. Oleh sebab itu, Akhadiah (Abidin, 2013:181) memandang menulis adalah sebuah proses, yaitu proses penuangan gagasan atau ide ke dalam bahasa tulis yang dalam praktiknya proses menulis diwujudkan dalam beberapa tahapan yang merupakan satu sistem yang utuh. Menulis memiliki kesamaan makna dengan mengarang yaitu segenap kegiatan seseorang mengungkapkan gagasan dan menyampaikannya melalui bahasa tulis kepada pembaca untuk dipahami (Abidin, 2013:181). Dari definisi ini dapat dikemukakan bahwa menulis adalah sebuah proses berkomunikasi secara tidak langsung antara penulis dengan pembacanya.

Produk menulis yang dihasilkan seorang penulis diproduksi melalui berbagai tahapan. Tahapan tersebut terbentang dari tahap pemerolehan ide, pengolahan ide hingga pemroduksian ide. Pada tahap pemerolehan ide, penulis mendaya-gunakan kepekaannya untuk mereaksi berbagai fenomena hidup dan kehidupan manusia yang diketahuinya melalui berbagai peranti pemerolehan ide. Pada tahap pengolahan ide, penulis akan mendayagunakan beberapa kemampuan meliputi kemampuan berpikir, kemampuan berasa, dan kemampuan berimajinasi. Pada tahap pemroduksian ide, penulis akan menggunakan peranti produksi ide yakni pengetahuan bahasa dan pengetahuan konvensi karya. Pengetahuan bahasa merupakan peranti utama yang digunakan oleh penulis dalam mengemas gagasan yang telah diolahnya. Melalui penggunaan pengetahuan atau kemampuan berbahasa ini sebuah ide 
dikemas sesuai dengan tujuannya serta memenuhi asas ketatabahasaan yang berterima di kalangan pembacanya (Abidin, 2013:184).

Menulis merupakan aktivitas yang dilakukan setelah peserta didik menguasai pembelajaran bahasa yang lainnya seperti mendengarkan, berbicara, dan membaca. Dibandingkan dengan kemampuan berbahasa yang lainnya menulis merupakan kemampuan bahasa yang lebih sulit jika dibandingkan dengan yang lainnya. Hal ini disebabkan kemampuan menulis menghendaki penguasaan berbagai unsur kebahasaan dan unsur di luar bahasa itu sendiri yang akan menjadi tulisan (Iskandarwassid \& Sunendar, 2009:248).

Menulis merupakan keterampilan berbahasa yang dipergunakan untuk berkomunikasi secara tidak langsung, tidak secara tatap muka dengan orang lain (Tarigan, 2013:3). Menulis merupakan salah satu cara yang dapat digunakan untuk menyampaikan informasi kepada orang lain bukan melalui percakapan atau bertatap muka secara langsung, akan tetapi melalui tulisan. Menurut Tarigan (2013:4), menulis merupakan kegiatan yang produktif dan ekspresif. Dalam kegiatan menulis sang penulis harus terampil dalam memanfaatkan grafologi, struktur bahasa, dan kosa kata.

Kegiatan menulis merupakan kegiatan yang menuntut penulis agar berpikir aktif, terutama pada saat kegiatan untuk menyusun kalimat sehingga dapat menghasilkan tulisan yang utuh. Ketrampilan menulis juga tidak didapatkan secara otomatis, keterampilan menulis didapatkan melalui latihan dan praktik yang banyak juga teratur. Keterampilan menulis dalam kehidupan modern sangat dibutuhkan, karena orang yang terpelajar cenderung memiliki keterampilan dalam menulis. Begitu pula dengan yang disampaikan oleh Morsey (dalam Tarigan, 2013:122) menulis dipergunakan oleh orang terpelajar untuk mencatat/merekam, meyakinkan, melaporkan/memberitahukan, dan mempengaruhi; dan maksud serta tujuan seperti itu hanya dapat dicapai dengan baik oleh orang-orang yang dapat menyusun pikirannya dan mengutarakannya dengan jelas, kejelasan ini tergantung pada pikiran, organisasi, pemakaian kata-kata, dan struktur kalimat.

Mengingat pentingnya keterampilan menulis, terutama dalam kehidupan modern sekarang ini, maka dalam pembelajaran bahasa Indonesia keterampilan tersebut diajarkan. Pembelajaran keterampilan menulis di sekolah meliputi tiga tingkat yaitu, tingkat pemula, tingkat menengah, dan tingkat lanjut. Di bawah ini adalah beberapa tujuan pembelajaran mengingat pentingnya keterampilan menulis, terutama dalam pembelajaran bahasa Indonesia di sekolah.

\section{Teks Prosedur Kompleks}

Halliday dan Ruqiyah (1992) dalam Mahsun (2014:1) menyebutkan teks merupakan jalan menuju pemahaman tentang bahasa. Mahsun (2014:1) teks merupakan satuan bahasa yang digunakan sebagai ungkapan suatu kegiatan sosial baik secara lisan maupun tulis dengan struktur berpikir yang lengkap. Pembelajaran bahasa Indonesia dalam Kurikulum 2013 diorientasikan pada pembelajaran berbasis teks karena dapat membantu siswa dalam memahami makna yang terkandung dalam sebuah teks misalnya teks prosedur kompleks. Siswa akan mampu memahami makna yang terkandung dalam teks prosedur yang diberikan oleh guru.

Teks berdasarkan Kamus Besar Bahasa Indonesia (2008) adalah naskah yang berupa kata-kata asli dari pengarang. Teks adalah satuan bahasa yang digunakan sebagai ungkapan suatu kegiatan sosial baik secara lisan maupun tulisan dengan struktur berpikir yang lengkap (Mahsun 2014: 1). 
Sedangkan prosedur menurut Majid (2011:46) adalah urutan langkah untuk mencapai suatu tujuan, memecahkan masalah tertentu, atau membuat sesuatu. Materi jenis prosedur berupa langkahlangkah mengerjakan sesuatu secara urut, misalnya wudhu, salat, naik haji, langkahlangkah menelepon, cara-cara pembuatan bel listrik, dsb.

Menurut Mahsun (2014:30) teks prosedur/arahan merupakan salah satu dari jenis teks yang termasuk genre faktual subgenre prosedural. Tujuan sosial teks ini adalah mengarahkan atau mengajarkan tentang langkah-langkah yang telah ditentukan. Dengan demikian teks jenis ini lebih menekankan aspek bagaimana melakukan sesuatu, yang dapat berupa salah satu percobaan atau pengamatan.

Prosedur kompleks berisi langkahlangkah praktis yang dapat mempermudah kehidupan. Membaca prosedur kompleks bermanfaat agar kita memahami petunjuk untuk mengerjakan hal-hal yang spesifik dalam kehidupan sehari-hari. Teks prosedur kompleks dapat kita temukan di majalah atau surat kabar (Kosasih, 2013:127).

Prosedur kompleks istilah populernya adalah trik atau kiat. Prosedur kompleks merupakan teks yang menjelaskan langkah-langkah secara lengkap dan jelas tentang cara melakukan sesuatu (Kosasih, 2013:131).

Teks prosedur kompleks merupakan teks yang mengutamakan ketepatan dalam hal urutan. Langkah-langkah kegiatan yang kita kemukakan harus benar. Kekeliruan dalam urutan bisa menyebabkan hasil dari kegiatan menjadi gagal atau bahkan mencelakakan. Perbandingan dengan teks lain, prosedur kompleks berbeda dalam hal banyaknya penggunaan kalimat perintah. Kalimat-kalimat itu disusun secara berurutan menurut urutan waktu atau urutan penting ke tidak penting. Analisis teks prosedur kompleks mengikuti struktur dan kaidah.
Berdasarkan analisis itu, dapat diketahui kelengkapan suatu teks prosedur kompleks. Dengan evaluasi, kita dapat memahami dan dapat memanfaatkannya sebagai sarana untuk melakukan prosedur pada bidang-bidang tertentu (Kosasih, 2013:143) .

Prosedur kompleks adalah teks yang berisi petunjuk untuk melakukan sesuatu. Menurut Kosasih (2014:67) bahwa teks prosedur kompleks adalah teks yang menjelaskan langkah-langkah secara lengkap, jelas, dan terperinci tentang cara melakukan sesuatu. Sedangkan, Tim Kemendikbud (2013:38) menyatakan, bahwa teks prosedur berisi langkahlangkah atau tahap-tahap yang harus ditempuh untuk mencapai suatu tujuan.

\section{Model Pembelajaran Discovery Learning}

Penemuan (discovery) merupakan suatu model pembelajaran yang dikembangkan berdasarkan pandangan konstruktivisme. Menurut Kurniasih \& Sani (2014: 64) discovery learning didefinisikan sebagai proses pembelajaran yang terjadi bila materi pembelajaran tidak disajikan dalam bentuk finalnya, tetapi diharapkan siswa mengorganisasi sendiri. Selanjutnya, Sani (2014:97) mengungkapkan bahwa discovery adalah menemukan konsep melalui serangkaian data atau informasi yang diperoleh melalui pengamatan atau percobaan.

Pernyataan lebih lanjut dikemukakan oleh Hosnan (2014:282) bahwa discovery learning adalah suatu model untuk mengembangkan cara belajar aktif dengan menemukan sendiri, menyelidiki sendiri, maka hasil yang diperoleh akan setia dan tahan lama dalam ingatan. Melalui belajar penemuan, siswa juga bisa belajar berpikir analisis dan mencoba memecahkan sendiri masalah yang dihadapi. WilcoXI (dalam Hosnan, 2014:281) menyatakan bahwa dalam pembelajaran dengan penemuan, siswa didorong untuk belajar sebagian besar melalui keterlibatan aktif mereka 
sendiri dengan konsep-konsep dan prinsip-prinsip dan guru mendorong siswa untuk memiliki pengalaman dan melakukan percobaan yang memungkinkan mereka menemukan prinsip-prinsip untuk diri mereka sendiri.

Model discovery merupakan pembelajaran yang menekankan pada pengalaman langsung dan pentingnya pemahaman struktur atau ide-ide penting terhadap suatu disiplin ilmu, melalui keterlibatan siswa secara aktif dalam pembelajaran. Bahan ajar yang disajikan dalam bentuk pertanyaan atau permasalahan yang harus diselesaikan. Jadi siswa memperoleh pengetahuan yang belum diketahuinya tidak melalui pemberitahuan, melainkan melalui penemuan sendiri.

Bruner (dalam Kemendikbud, 2013b:1) mengemukakan bahwa proses belajar akan berjalan dengan baik dan kreatif jika guru memberikan kesempatan pada siswa untuk menemukan suatu konsep, teori, aturan, atau pemahaman melalui contoh-contoh yang dijumpai dalam kehidupannya. Penggunaan discovery learning, ingin merubah kondisi belajar yang pasif menjadi aktif dan kreatif. Mengubah pembelajaran yang teacher oriented ke student oriented. Mengubah modus Ekspositori, siswa hanya menerima informasi secara keseluruhan dari guru ke modus discovery, siswa menemukan informasi sendiri. Sardiman (dalam Kemendikbud, 2013b: 2) mengungkapkan bahwa dalam mengaplikasikan model discovery learning guru berperan sebagai pembimbing dengan memberikan kesempatan kepada siswa untuk belajar secara aktif, guru harus dapat membimbing dan mengarahkan kegiatan belajar siswa sesuai dengan tujuan.

\section{Media Pembelajaran Audio Visual}

Media audio visual merupakan salah satu jenis media pembelajaran yang dapat digunakan dalam proses pembelajaran. Asyhar (2011:45) mendefinisikan bahwa media audio visual adalah jenis media yang digunakan dalam kegiatan pembelajaran dengan melibatkan pendengaran dan penglihatan sekaligus dalam satu proses atau kegiatan. Pesan dan informasi yang dapat disalurkan melalui media ini dapat berupa pesan verbal dan nonverbal yang mengandalkan baik penglihatan maupun pendengaran. Beberapa contoh media audio visual adalah film, video, program TV dan lain-lain.

Sementara itu, Asra (2007:5-9) mengungkapkan bahwa media audio visual yaitu media yang dapat dilihat sekaligus dapat didengar, seperti film bersuara, video, televisi, dan sound slide. Sedangkan Rusman menjelaskan bahwa media audio visual yaitu media yang merupakan kombinasi audio dan visual atau bisa disebut media pandang-dengar. Contoh dari media audio-visual adalah program video/ televisi pendidikan, video/televisi instruksional, dan program slide suara (sound slide).

Berdasarkan penjelasan di atas dapat disimpulkan bahwa media audio visual merupakan media yang dapat digunakan dalam kegiatan pembelajaran dengan melibatkan pendengaran dan penglihatan sekaligus dalam satu proses atau kegiatan. Contoh media audio visual adalah film, video, program TV, slide suara (sound slide) dan lain-lain.

Pembelajaran menggunakan teknologi audio visual adalah satu cara menyampaikan materi dengan menggunakan mesin-mesin mekanis dan elektronis untuk menyajikan pesan-pesan audio visual. Arsyad (2011:31) mengemukakan bahwa media audio visual memiliki karakteristik bersifat linear, menyajikan visual yang dinamis, digunakan dengan cara yang telah ditetapkan sebelumnya oleh perancang/pembuatnya, dapat memberikan gambaran fisik dari gagasan real atau abstrak, dikembangkan menurut prinsip psikologis behaviorisme dan 
kognitif, dan berorientasi pada guru dengan tingkat penglihatan interaktif murid yang rendah.

\section{METODE PENELITIAN}

Metode penelitian yang digunakan adalah metode penelitian dan pengembangan (Research and Development/R\&D). Penelitian R\&D adalah proses yang digunakan untuk mengembangkan dan memvalidasi produk pendidikan. Langkah-langkah R\&D terdiri atas menemukan dan menganalisis sebuah produk, mendesain, mengembangkan produk, mengimplementasikan, dan merevisinya untuk memperbaiki kekurangan yang ditemukan dalam tahap mengajukan pengujian (Sugiyono, 2016:28).

Borg \& Gall dalam Nana Syaodih Sukmadinata (2006:169-170) memaparkan sepuluh langkah pelaksanaan strategi penelitian dan pengembangan sebagai berikut: (1) penelitian dan pengumpulan data (research and information collecting), (2) perencanaan (planning), (3) pengembangan draf produk (develop preliminary form of product), (4) uji coba lapangan awal (preliminary field testing), (5) merevisi hasil uji coba (main product revision), (6) uji coba lapangan (main field testing), (7) penyempurnaan produk hasil uji lapangan (operasional product revision), (8) uji pelaksanaan lapangan (operasional field testing), (9) penyempurnaan produk akhir (final product revision), dan (10) diseminasi dan implementasi (dissemination and implementation).

Data yang dikumpulkan dalam pengembangan bahan ajar ini adalah data kuantitatif dan kualitatif. Data kuantitatif diperoleh dari hasil pengisian angket oleh peserta didik pada uji coba lapangan. Data kuantitatif selanjutnya akan diolah menggunakan rumus yang ada agar dapat dideskripsikan. Data kualitatif diperoleh dari hasil validasi oleh ahli desain, ahli bahasa, dan ahli materi.
Teknik pengumpulan data dalam penelitian ini adalah wawancara kepada guru dan siswa untuk mengetahui tanggapan mereka terhadap bahan ajar menulis teks prosedur kompleks dengan model pembelajaran discovery learning menggunakan media audio visual (video), angket dan tes perolehan hasil belajar.

\section{HASIL DAN PEMBAHASAN}

Produk pengembangan yang dihasilkan adalah bahan ajar berupa buku pegangan dengan materi Teks Prosedur Kompleks sebagai buku penunjang atau buku pegangan belajar siswa dan pegangan guru dalam melaksanakan proses pembelajaran terutama materi Teks Prosedur Kompleks dalam pembelajaran Bahasa Indonesia kelas XI SMAN 1 Samarinda dalam mencapai hasil belajar yang memuaskan.

Wujud akhir dari produk pengembangan bahan ajar adalah buku pegangan siswa dalam materi teks prosedur kompleka. Tujuan pengembangan bahan ajar yaitu Menulis Teks Prosedur Kompleks Dengan Model Pembelajaran Discovery Learning Menggunakan Media Video untuk memperlancar dan memberikan bantuan informasi materi pembelajaran sebagai pegangan siswa, sehingga dapat menumbuhkan minat belajar yang nantinya akan berpengaruh pada hasil belajar siswa.

Pengembangan bahan ajar berupa berupa buku pegangan ini didasarkan pada kenyataan bahwa masih banyaknya bahan ajar cetak terbitan dari tim yag masih memiliki beberapa kekurangan sehingga perlu adanya bahan ajar yang menunjang proses pembelajaran didalam kelas.

Hasil pengembangan ini dimaksudkan untuk dapat memenuhi tersedianya bahan ajar yang dapat meningkatkan keefektifan dan kemenarikan dalam pembelajaran Bahasa Indonesia di SMAN 1 Samarinda dalam mencapai hasil pendidikan yang telah 
ditetapkan kurikulum.

Berdasarkan model penelitian yang telah dipilih maka, proses penelitian meliputi beberapa proses sebagai berikut.

\section{Penelitian dan Pengumpulan Informasi Awal}

Langkah pertama yang dilakukan oleh peneliti adalah melakukan wawancara awal terhadap guru kelas XI SMAN 1 untuk menganalisis kebutuhan. Kegiatan ini dilakukan dengan cara wawancara kepada guru kelas serta mengamati bahan ajar yang digunakan dalam pembelajaran Bahasa Indonesia materi Teks Prosedur Kompleks kelas XI SMA. Berdasarkan hasil wawancara dengan guru kelas XI SMAN 1 Samarinda, guru menjelaskan bahwa buku yang digunakan siswa dalam pembelajaran dikelas hanya sebatas buku paket dan LKS. Sedangkan hasil pengamatan menunjukkan bahwa bahan ajar yang digunakan dalam pembelajaran Bahasa Indonesia menggunakan bahan ajar cetak berupa buku dan LKS.

\section{Perencanaan}

Perencanaan penelitian R\&D meliputi: merumuskan tujuan penelitian, memperkirakan dana, tenaga dan waktu dalam penelitian. Berdasarkan informasi awal, peneliti ingin mengembangkan buku pegangan siswa sebagai bahan ajar. Tujuannya adalah untuk menghasilkan desain bahan ajar buku pegangan siswa pada materi teks prosedur kompleks dalam pembelajaran Bahasa Indonesia, menjelaskan kemenarikan bahan ajar teks prosedur kompleks dengan buku pegangan siswa dan juga menggunakan video pembelajaran dalam pembelajaran Bahasa Indonesia, dan menjelaskan peningkatan hasil belajar siswa dengan menggunakan produk bahan ajar buku pegangan siswa pada materi teks prosedur kompleks serta menggunakan video pembelajaran dalam model pembelajaran discovery learning di kelas XI SMAN 1 Samarinda.
Setelah itu peneliti juga harus bisa memperkirakan dana, tenaga dan waktu. Untuk dana, peneliti sebisa mungkin untuk meminimalisir dana yang akan dikeluarkan. Sedangkan tenaga dan waktu, peneliti memprediksi pembuatan produk yang akan selesai dalam kurun waktu 1 bulan dan akan melakukan penelitian selama kurang lebih 2 bulan untuk menyelesaikan penelitian pengembangan ini mulai dari tahap observasi sampai uji coba lapangan.

\section{Pengembangan Format Produk Awal}

Setelah merumuskan perencanaan, peneliti mulai membuat produk bahan ajar teks prosedur kompleks dengan model pembelajaran discovery learning menggunakan media video yang akan dapat membantu siswa dalam proses pembelajaran sebagai buku supplement dalam mempelajari materi sumber energi yang di desain semenarik mungkin sehingga menimbulkan hasil belajar dalam diri siswa untuk belajar dan akan berdampak pada hasil nilai belajar siswa yang lebih memuaskan. Akhir dari pembuatan bahan ajar teks prosedur kompleks adalah melakukan publish terhadap produk agar siap untuk dilakukan uji coba. Tidak hanya itu peneliti juga harus menentukan sarana dan prasarana penelitian yang akan dibutuhkan selama proses penelitian pengembangan.

\section{Uji Coba Awal}

Uji coba awal dilakukan kepada tiga orang pakar, yaitu: pakar pengembangan media pembelajaran, pakar ahli bahasa, dan pakar ahli materi untuk memperoleh validitas sebuah produk. Peneliti menetapkan validator untuk menilai tingkat kevalidan media yang dikembangkan. Peneliti memilih Atik Sri Rahayu, M.Pd. sebagai validasi ahli materi, Rus Suharto, M.Pd. sebagai validasi ahli bahasa, dan M. Agus Kastiyawan, M.Pd. sebagai validasi ahli media. 


\section{Revisi Produk}

Berdasarkan hasil uji coba awal, peneliti melakukan perbaikan produk pengembangan masukan dari pakar media dan ahli pembelajaran.

\section{Uji Lapangan}

Setelah revisi, peneliti perlu menguji cobakan pada siswa satu kelas. Dalam penelitian ini uji coba dilakukan pada kelas XI MIPA 3 SMAN 1 Samarinda. Untuk mengukur kemampuan siswa yang menggunakan produk yang dikembangkan dengan yang tidak memakai produk yang dikembangkan, dengan menggunakan Pre-test dan Posttest.

\section{Revisi Produk Akhir}

Setelah diujikan, maka peneliti masih perlu melakukan revisi pada hasil dari uji coba lapangan untuk memperoleh hasil maksimal

\section{E. PENUTUP}

Berdasarkan proses pengembangan hasil validasi dan pembahasan terhadap bahan ajar menulis teks prosedur kompleks dengan model pembelajaran discovery learning menggunakan media video di kelas XI SMAN 1 Samarinda, maka dapat disimpulkan hasil penelitian sebagai berikut.

Perencanaan bahan ajar yang dikembangkan berupa buku pegangan siswa dengan materi teks prosedur kompleks dengan dengan model pembelajaran discovery learning menggunakan media video untuk meningkatkan hasil belajar siswa kelas XI SMAN 1 Samarinda. Produk yang dikembangkan juga telah memenuhi komponen sebagai bahan ajar yang baik untuk digunakan dikarenakan bahan ajar telah sesuai dengan KI-KD, sesuai dengan keadaan siswa, bahasa yang digunakan mudah, dan juga memiliki kesesuaian warna, gambar video dengan materi, ukuran dan jenis huruf menarik yang akan memotivasi siswa agar lebih bersemangat belajar sehingga hasil belajar juga menjadi meningkat.

Penerapan bahan ajar model pembelajaran discovery learning menggunakan media video kelas XI adalah sebagai berikut. Pertama memberi stimulasi. Guru membagikan buku pegangan siswa dan menanyangkan video pembelajaran. Siswa menonton tayangan video pembelajaran "Cara Mengurus SIM". Kedua, problem statemen (pernyataan/identifikasi masalah). Guru memberikan kesempatan kepada siswa mengidentifikasi masalah-masalah yang relevan dengan bahan pelajaran, kemudian salah satunya dipilih dan dirumuskan dalam bentuk hipotesis. Ketiga, data processing (pengolahan data). Siswa mendiskusikan, menyunting, penyempur-naan teks prosedur kompleks yang ada dengan panduan tayangan video pembelajaran "Cara Mengurus SIM" dari Sumber Satlantas Polres Jombang. Siswa menjawab pertanyaan tugas buku pegangan siswa menukis teks prosedur kompleks dan pertanyaan yang disampaikan oleh guru dengan disesuaikan oleh materi. Keempat, verification (pembuktian). Siswa melakukan pemeriksaan secara cermat untuk membuktikan benar atau tidaknya hipotesis yang ditetapkan tadi dengan temuan alternative dan dihubungkan dengan hasil pengolahan data. Kelima, generalization (menarik kesimpulan). Siswa mempresentasikan hasil kerja kelompok dan kelompok lain member tanggapan yang dapat dijadikan prinsip umum dan berlaku untuk semua kejadian atau masalah yang sama, dengan memperhatikan verifikasi.

Perolehan hasil belajar berdasarkan uji lapangan kelas XI SMAN 1 Samarinda yang diukur dengan menggunakan tes pencapaian hasil belajar. Berdasarkan analisis yang telah dilakukan menunjukkan bahwa $t_{\text {bitung }}>t_{\text {tabel }}$ sehingga dapat disimpulkan bahwa ada pengaruh signifikan Hasil uji coba lapangan didapat 
hasil uji $t$ yang dihitung secara manual menunjukkan hasil $t_{\text {hitung }}=13,68>t_{\text {tabel }}=$ 1,703 , sehingga dapat meningkatkan hasil belajar siswa yang diketahui melalui peningkatan rata-rata nilai kelas yang diperoleh melalui pre-test $(51,8)$ dan post-test $(80,9)$.

\section{DAFTAR PUSTAKA}

Abidin, Y. (2013). Pembelajaran Bahasa Berbasis Pendidikan Karakter. Bandung: Refika Aditama.

Abidin, Y. (2016). Desain Sistem Pembelajaran dalam Konteks Kurikulum 2013. Bandung: Refika Aditama.

Arsyad, A. (2016). Media Pembelajaran. Jakarta: Raja Grafindo Persada.

Basuni, L. (2018). Pengembangan Perangkat Pembelajaran Menulis Pantun Melalui Model Pembelajaran Example Non-Example Siswa Kelas X SMA. Imu Budaya (Jurnal Bahasa, Sastra, Seni dan Budaya), 2(1), 17 - 24. http://ejournals.unmul.ac.id/index.php/JB $\underline{\mathrm{SSB} / \text { article/view/849 }}$

Dimyati \& Mudjiono. (2013). Belajar dan Pembelajaran. Jakarta: Rineka Cipta.

Djamarah, Bahri, S., \& Zain, A. (2010). Strategi Belajar Mengajar. Jakarta: Rineka Cipta.

Kastiyawan, M., Hudiyono, Y., \& Ahmad, M. (2017). Pengembangan Media Levidio Storyboard dalam Pembelajaran Menulis Teks Ulasan Film/Drama pada Siswa Kelas XI SMK. CaLLs (Journal of Culture, Arts, Literature, and Linguistics), 3(1), 15 30.

doi:http://dx.doi.org/10.30872/cal ls.v3i1.774

Komalasari, K. (2014). Pembelajaran Kontekstual Konsep dan Aplikasi. Bandung: Refika Aditama.
Kosasih, E. (2013). Kreatif Berbahasa Indonesia. Jakarta: Erlangga.

Kulsum, U., Hudiyono, Y., \& Sulistyowati, E. D. (2018). Pengembangan Bahan Ajar Menulis Cerpen dengan Media Storyboard pada Siswa Kelas X SMA. Diglosia: Jurnal Kajian Bahasa, Sastra, dan Pengajarannya, 1(1), 1-12. Diperoleh dari http://jurnal.fkip.unmul.ac.id/inde x.php/diglosia/article/view/2

Lestari, I. (2013). Pengembangan Baban Ajar Berbasis Kompetensi. Padang: Akademia Permata.

Mahsun. (2014). Teks dalam Pembelajaran Bahasa Indonesia Kurikulum 2013. Jakarta: Raja Grafindo Persada.

Majid, A. (2011). Perencanaan Pembelajaran. Bandung: Remaja Rosdakarya.

Margono. (2013). Metodelogi Penelitian Pendidikan. Jakarta: Rineka Cipta.

Mugianto, M., Ridhani, A., \& Arifin, S. (2017). Pengembangan Perencanan Pembelajaran Menulis Teks Laporan Hasil Observasi Model Pembelajaran Berbasis Proyek Siswa Kelas X SMA. Ilmu Budaya (Jurnal Bahasa, Sastra, Seni dan Budaya), 1(4), 353-366. http://ejournals.unmul.ac.id/index.php/JB $\underline{\mathrm{SSB} / \text { article/view/769 }}$

Mursalim. (2017). Penumbuhan Budaya Literasi dengan Penerapan Ilmu Keterampilan Berbahasa (Membaca dan Menulis). CaLLs (Journal of Culture, Arts, Literature, and Linguistics), $\quad 3(1), \quad 31-38$. doi:http://dx.doi.org/10.30872/cal ls.v3i1.815

Rusman. 2012. Model-Model Pembelajaran. Jakarta: Raja Grafindo Persada.

Sari, E., Mursalim, \& Murtadlo, A. (2017). Pengembangan Teknik Pembelajaran Menulis dan Membaca Melalui Gerakan Literasi 
Sekolah. Ilmu Budaya (Jurnal Bahasa, Sastra, Seni dan Budaya), 1(4), 341352. http://e-

journals.unmul.ac.id/index.php/JB $\mathrm{SSB} /$ article/view/772

Sari, R., Hudiyono, Y., \& Soe'oed, R. (2017). Pengembangan Media Blog dalam Pembelajaran Menulis Teks Anekdot pada Siswa Kelas X SMA. Ilmu Budaya Jurnal Bahasa, Sastra, Seni dan Budaya), 1(4), 317330. http://e-

journals.unmul.ac.id/index.php/JB $\underline{\mathrm{SSB} / \text { article/view/712 }}$

Slavin, R. E. 1955. Cooperative Learning, Theory, Reserch and Practice. Boston: Allyn and Bacon

Sugiono. (2009). Metode Penelitian Kuantitatif, Kualitatif, R\&D. Bandung: Alfabeta.

Suharsimi \& Arikunto. (2002). Prosedur Penelitian Suatu Pendekatan Praktek. Jakarta: Rineka Cipta.

Suharsini, A. (2005). Dasar-Dasar Evaluasi Pendidikan. Jakarta: Bumi Aksara.
Suliani, N N. W. (2011). Media Pembelajaran dan Sastra Indonesia. Bandar Lampung: Universitas Lampung.

Tarigan, H. G. (2008). Menulis. Bandung: Angkasa.

Wati, E., Ilyas, M., \& Sulistyowati, E. (2017). Pengembangan Media Mobile Learning dalam Pembelajaran Menulis Deskripsi pada Siswa Kelas X SMK. Ilmu Budaya (Jurnal Babasa, Sastra, Seni dan Budaya), 1(4), 291-304. http://ejournals.unmul.ac.id/index.php/JB $\underline{\mathrm{SSB} / \text { article/view/770 }}$

Windhiarty, W., Haruna, J., \& Sulistyowati, E. (2017). Efektivitas Pembelajaran Menulis Teks Eksplanasi dengan Media Berbasis Adobe Flash Siswa Kelas XI SMA. Ilmu Budaya Jurnal Bahasa, Sastra, Seni dan Budaya), 1(4), $367-$ $376 . \quad$ http://ejournals.unmul.ac.id/index.php/JB $\underline{\mathrm{SSB} / \text { article/view/768 }}$ 
